\title{
IMIGRACE ANGLICKY MLUVÍCÍCH (RODILÝCH MLUVČÍCH) DO ČESKÉ REPUBLIKY
}

IMMIGRATION OF ENGLISH SPEAKING (NATIVE) POPULATION IN THE CZECH REPUBLIC

\author{
MGr. LUKÁŠ NEVĚDĚL, PH.D. \\ BC. SABINA ŠTIBOROVÁ \\ Ústav demografie a aplikované statistiky $\mid$ Department of Demography and Aplied Statistics \\ Fakulta regionálního rozvoje a mezinárodních studii $\quad$ Faculty of Reg.Development and International Studies \\ Mendelova univerzita v Brně Mendel University in Brno \\ $\triangle$ Tř́la Generála Píky 7, 61300 Brno, Czech Republic \\ E-mail: lukas.nevedel@mendelu.cz,xstiboro@node.mendelu.cz
}

\begin{abstract}
Anotace
Cílem př̀spěvku je prezentace intenzity migrace dle statistiky dat, di̊vodů a motivaci emigrantù z USA, Spojeného království, Kanady a Austrálie do České republiky. Zjištěni důvodů a motivací k emigraci ze své rodné zemé, zváženi kladi̊ a zápori̊ pobytu v České republice, uplatněni se na trhu práce, integrace a akceptace českou společností a srovnáni očekáváni s realitou byly shromažd'ovány pomoci kvalitativnich metod výzkumu. Intenzita imigrace je dále prognózována do budoucnosti pomoci časové rady na roky 2012 a 2013. Ziskané výsledky byly srovnány s výzkumem preferenci české společnosti, jakým zpưsobem vnimá výše zminěné imigranty a jak jejich imigraci vidí - jako př́nos a príležitost či naopak.
\end{abstract}

\section{Klíčová slova}

imigrace, integrace, trh práce, Česká republika

\section{Annotation}

The main object of this thesis is presentation of migration strength - on the basis of hard data, the reasons and motivation of emigrants from USA, UK, Canada and Australia to Czech Republic. Determination the reasons and motivation to emigrate from their native country, consider the Pros and Cons of immigration to Czech Republic, success at the labour market, integration and acceptance of Czech society and comparison their expectation and reality were collected using qualitative research methods. The intensity of immigration is predicting further into the future. These results were compared with the research of Czech society, how they perceive the above mention immigrants, if they see their immigration as benefit and opportunity in favour or vice versa.

\section{Key words}

immigration, integration, labour market, Czech Republic

JEL classification: J61

\section{Úvod}

Česká republika v nedávné minulosti čelila po roce 1989 zvýšené imigraci. Touha po lepší životní úrovni, živelné pohromy, nevyhovující politický systém a mnoho dalších jsou důvody nutící obyvatelstvo opustit svou rodnou zemi. Mezi hlavní důvody migrace se řadí důvody ekonomické, politické, etnické, sociální, náboženské a další. Velká část těchto přistěhovalců se řadí mezi ekonomicky aktivní obyvatelstvo, které do České republiky přichází za účelem uplatnit se na trhu 
práce nejčastěji $\mathrm{v}$ těch sektorech, kde domácí obyvatelstvo není dostatečně motivováno pracovat z důvodů nedostatečného finančního ohodnocení. O migraci tohoto typu je napsána celá řada studií. Avšak v případě emigrace $\mathrm{z}$ anglicky mluvících zemí jako je Spojené království, Spojené státy americké, Kanada, Austrálie a dalších tyto důvody až tak zřejmé nejsou. Vývoj migrace je velice obtížné odhadnout, avšak nejčastěji se odvíjí od fází hospodářského cyklu. V př́ípadě fáze recese je sledován právě pokles imigrace. Platí tento pokles i pro nestandardní imigranty? Na podobné otázky si klade odpovědi a zkoumá souvislosti následující text př́spěvku.

\section{Cíl a metody}

Cílem práce je zjistit, zda motivem anglicky mluvících obyvatel, kteří imigrovali do České republiky, je zlepšení jazykových znalostí místních obyvatel a vyšší zapojení země do světové ekonomiky. Cílem příspěvku bylo zjištění subjektivního hodnocení jejich uplatnění na trhu práce, co bylo motivací při výběru země, co považují za klady a zápory České republiky. Bylo třeba zjistit názory a postoje české společnosti k těmto imigrantům. Klíčovými otázkami bylo, zda tuto skupinu imigrantů vnímají občané ČR jako př́ležitost ve svůj rozvoj nebo jako „nežádouci““ konkurenci.

V kvantitativní části bude vystihnut vývoj a význam imigrace (Hübelová, 2012) v České republice celkově a zvláště pro anglicky mluvící cizince se zohledněním ekonomické recese a jejího vlivu na regionální rozvoj (Chalupa - Hübelová, 2012). Součástí kvantitativní části je také prognóza, jakým způsobem se bude imigrace dále vyvíjet pro roky 2012 a 2013 s ohledem na dnešní ekonomickou recesi.

V práci jsou použity kvantitativní metody analýzy, statistické metody, časové řady (Minařík, 2008), a kvalitativní osobní rozhovory s imigranty na otevřené otázky. Zdrojem statistických dat byl Český statistický úřad, jenž se sběrem dat v dané oblasti rovněž zabývá.

Jednou z nejznámějších teorií, která se zabývá hledáním důvodů migrace je neoklasická teorie migrace push a pull faktorů. Vychází z toho, že při emigraci je jedinec ovlivněn působením faktorů přitahujících, pro které se používá anglický výraz pull, patřící k zemi cílové a faktorů odpuzujících, aneb push v rodné zemi, které jsou impulzem k opuštění (Drbohlav - Uherek, 2007). Dle Drbohlava (2009) je integrace proces, kterého se účastní obě strany. Nejen minoritní, ale i majoritní společnost se na začleňování imigrantů musí aktivně podílet. Dále integraci rozdělil do několika sfér, kde zahrnuje i zmíněnou integraci vnější, kterou charakterizují postoje majoritní společnosti. Jako stěžejní se uvádí integrace strukturální, aneb nabývání práv a určitého institucionálního postavení v prrijímací zemi. Kulturní integrace, jak již název napovídá, je přijímání kultury cílové země a zároveň akceptace behaviorálních změn imigranty. Sociální integrace je velice důležitá, tu si ovšem každý jedinec musí vytvořit sám prostřednictví navazování nových vztahů, přátelství a členství v nejrůznějších organizacích. Uspokojování potřeby a pocitu sounáležitosti je zahrnuto v integraci identifikační, která úzce souvisí se sociální integrací.

Imigrace je prvkem řešení klesajícího počtu a zároveň stárnutí obyvatel (snižuje se počet ekonomicky aktivního obyvatelstva), nízkou porodností, ale také chybějícího počtu pracovníků v určitých profesích (Vavrejnová 2011, s. 11 - 12). Díky imigraci roste nabídka práce, která sebou přináší na trh nové výrobky a služby, kvůli kterému se domácí obyvatelstvo může soustřed’ovat na takovou produkci, v níž dokáže být nejefektivnější. Jako další pozitivní efekt imigrace se dá označit platba daní legálními zaměstnanci a zaměstnavateli. $Z$ pohledu př́ijmu státu se kromě nákupu zboží a služeb, odvodu daně z př́ijmu dají zmínit také cla při vývozu zboží do mateřské země (Vavrejnová 2011, s. 13). Imigranti představují konkurenci domácímu obyvatelstvu na trhu práce, obzvlášt’ $\mathrm{v}$ zemích $\mathrm{s}$ vysokou nezaměstnaností. Tím vznikají negativní vztahy, předsudky vůči imigrantům a snaha je vyhostit ze země (Vavrejnová 2011), což je v době recese relevantní otázka.

Proces začleňování neboli integrace cizinců je poměrně dlouhý a složitý „,běh na dlouhou trat““. Základem je vytvoření rovnoprávných podmínek pro přistěhovalecké menšiny, především na rovině ekonomické, sociální, ve vzdělávacích zařízeních, zdravotnictví a v neposlední řadě v rovině právní. 
Ovšem i imigranti musí mít v procesu integrace svou zásluhu. Pravidla nejsou v každé zemi stejná, proto je nutné striktní dodržování pravidel a zákonů České republiky, již výše zmíněná znalost českého jazyka z důvodu začlenění se do společnosti a pracovního procesu (Vavrejnová 2011).

\section{Výsledky}

Imigrace cizinců do České republiky byla prakticky od sametové revoluce trvale v kladných číslech mimo roku 2000. Největší nárůst migračního salda v posledních 23 letech nastal v době, kdy Česká republika vstupovala do Evropské unie a následně do schengenského prostoru. $\mathrm{V}$ té samé době vrcholila ekonomická konjunktura, což se projevovalo v silném př́livu migrantů do České republiky.

\section{Obr. 1: Mezinárodní migrace České republiky ve čtyřech pĕtiletých kategoriích}

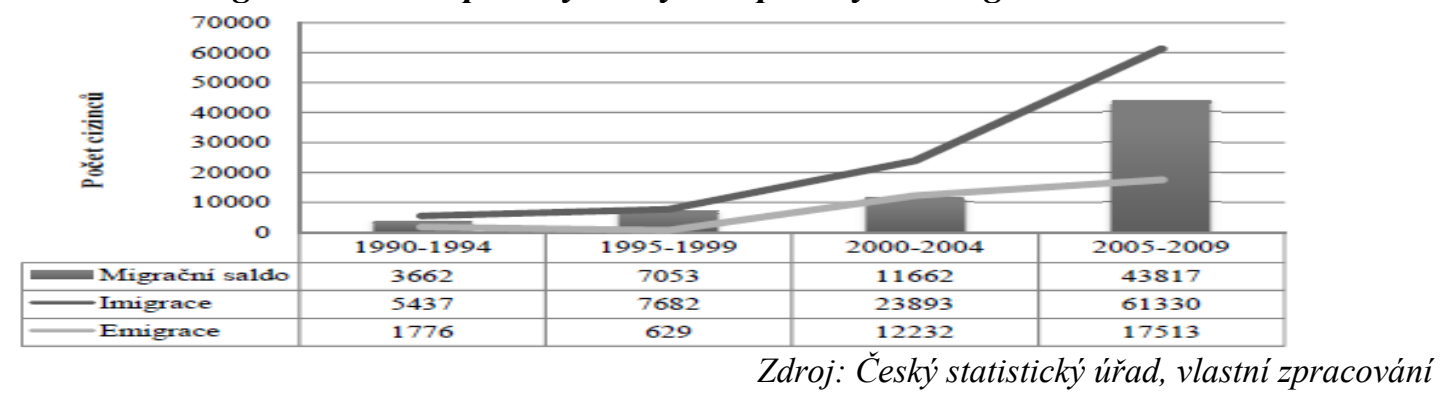

Významný nárůst imigrace do ČR byl zaznamenán po roce 1993. Jednou z nejvýznamnějších událostí, která ovlivnila imigraci, je vznik samostatné České republiky na začátku tohoto roku. Dřívější vnitrostátní pohyby obyvatelstva tak byly sledovány jako mezinárodní migrace. V dalších letech byla sledována stagnace, jednalo se o roky ekonomické recese v ČR. V roce 2000 došlo poprvé k propadu vinou změny metodiky. Opětovný dynamický nárůst zaznamenáváme po roce $2000 \mathrm{~s}$ vrcholem v roce 2007 díky vstupu do schengenského prostoru. V posledních třech letech časové řady (2009 - 2011) imigrace mírným tempem klesá. Tento pokles je především způsoben globální ekonomickou recesí. Odstartováním recese v polovině roku 2008 byla ovlivněna migrace po celém světě. Hospodářsky vyspělé země zaznamenaly postupné zmírňování, ba dokonce pokles př́chodu cizinců. $\mathrm{S}$ ekonomickou recesí jde ruku $\mathrm{v}$ ruce rostoucí míra nezaměstnanosti a malá poptávka po pracovní síle na domácím trhu (Horáková, 2010).

Obr. 2: Imigrace do České republiky v letech 1989 - 2011

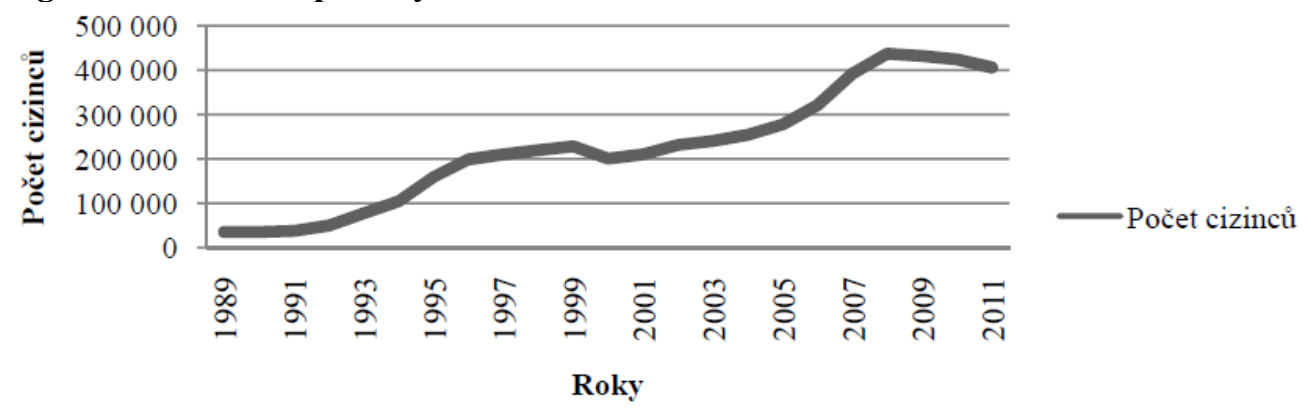

Zdroj: Český statistický úřad, vlastní zpracování

V obrázku 2 byla prezentována celková imigrace do České republiky, ta v posledních letech klesá. $\mathrm{V}$ př́ípadě anglicky mluvících imigrantů sledujeme stále nárůst tempa prírůstku. Ekonomická recese nemá tak významný dopad na kvalifikovanější pracovní sílu. 
Obr. 3: Vývoj počtu imigrantů ze Spojeného království a Spojených států amerických do České republiky v letech 2005 - 2011

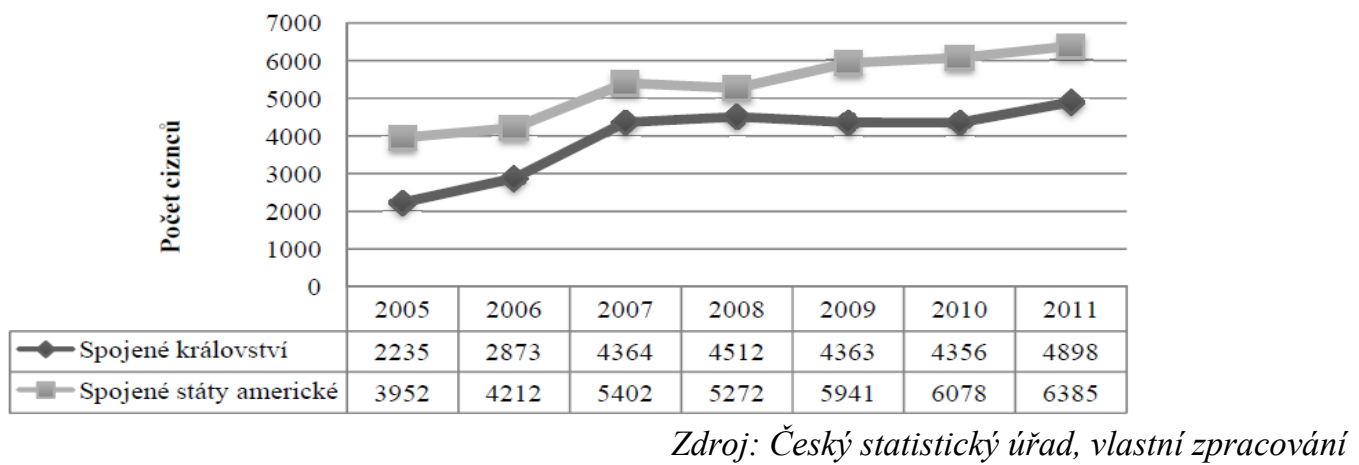

Pomocí časových řad byly vypočteny prognózy počtu imigrantů v letech 2012 a 2013.

Obr. 4: Prognóza vývoje celkové imigrace a imigrace anglicky mluvících do České republiky pro roky 2012 a 2013
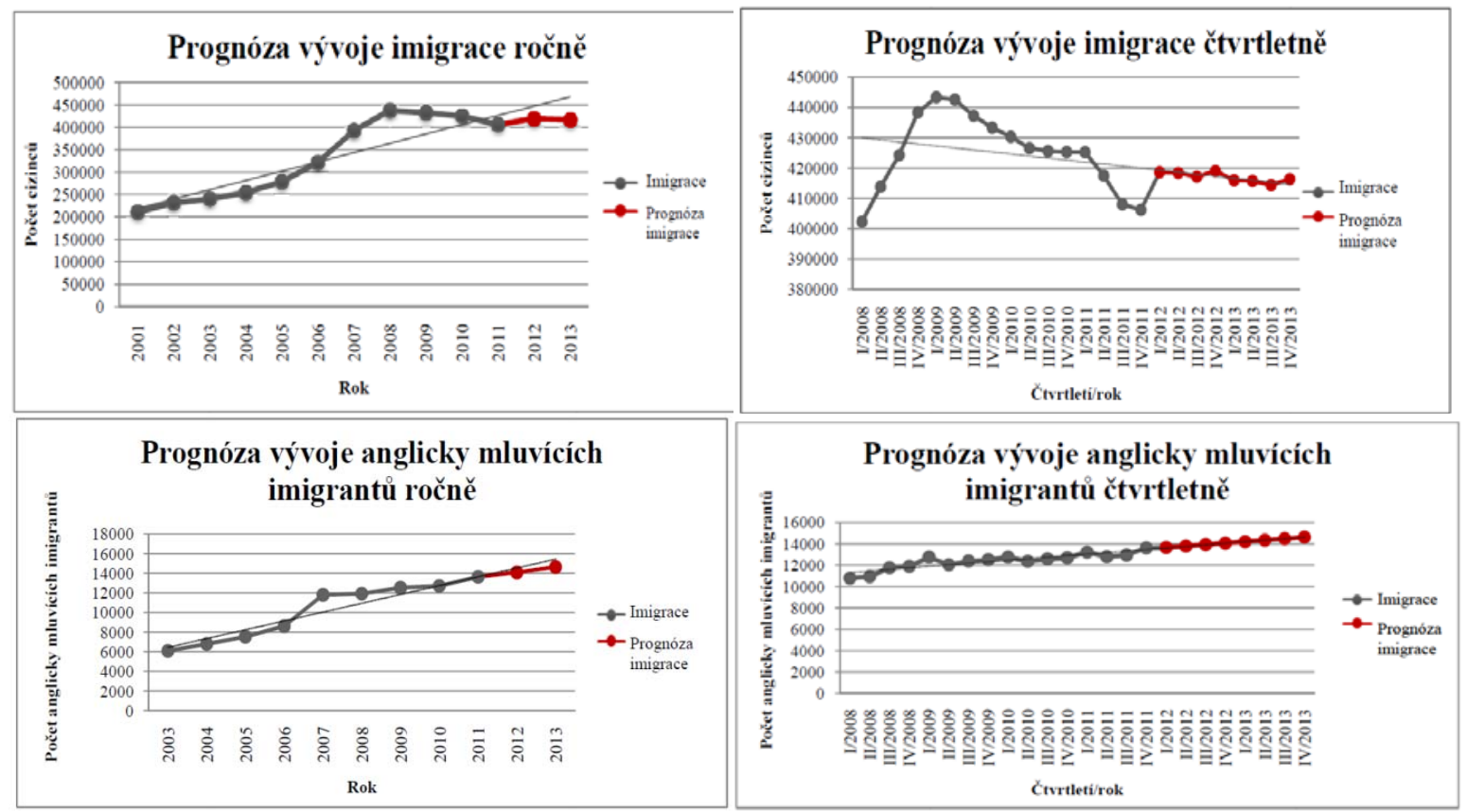

Zdroj: Český statistický úřad, vlastní zpracování

Terénní výzkum byl rozdělen na dvě části. První, stěžejní část, vychází z výzkumu mezi anglicky mluvícími imigranty. $V$ druhé části je na téma pohlíženo $z$ druhé perspektivy, čili proběhlo dotazování české společnosti, která hodnotila význam této skupiny lidí.

V následujícím textu jsou zpracovány a zanalyzovány odpovědi na otázky anglicky mluvících respondentů. Dotazovaných bylo celkem 20, z toho návratnost (ochota spolupracovat) byla šedesátiprocentní. Zbylých 40 \% nezodpovědělo na otázky z důvodu př́lišné časové vytíženosti nebo osobních důvodů. Respondenti souhlasili s osobní schůzkou, výzkum byl veden pomocí kvalitativních rozhovorů.

Mezi hlavní důvody a zároveň ty, které se objevily u většiny dotazovaných imigrantů, patří touha po poznání cizí země, jiné kultury, životního stylu a cizího jazyka. Českou republiku si dotazovaní zvolili především $\mathrm{z}$ důvodů příznivější nákladové dostupnosti bydlení a stravy. Jedním z pozoruhodných faktorů praktické části bylo zjištění, že všichni imigranti, kteři se do České republiky přistěhovali, jsou se životem v ní převážně spokojeni. Imigrantů z Velké Británie se nejvíce 
shodovali v odpovědi týkající se dobré kvality života v České republice. Obdivují pomalejší tempo života a velký význam mezigeneračních vztahů. Velkým lákadlem při výběru cílové země byla bohatá kultura. Pokud hodnotíme klady ČR, mezi klíčový po-klad patři česká kuchyně. Dle odpovědí bylo zřejmě, že se v naší zemi lze poměrně obstojně pobavit ve volném čase a navštívit řadu pamětihodností. Př́slušníci státu EU vyzdvihují jako pozitivum především uplatnění se na trhu práce, konkrétně na trhu TEFL (TEFL = teaching English as foreign language / výuka angličtiny jako cizího jazyka) a také dobré prostředí a př́ležitosti pro podnikání. Dva z dotazovaných mají svůj vlastní podnik, ve kterém také využivají svých jazykových znalostí. Velkým kladem, který je shodný pro všechny země EU, je výborná dopravní dostupnost mezi všemi členskými státy EU. Jako výhodu imigrace do České republiky rovněž uvádějí, dobrou znalost anglického jazyka těch, se kterými přichází do kontaktu a relativně vysoký počet příslušníkủ ČR ovládající angličtinu celkově na komunikační úrovni. Umožňuje jim to snadněji se integrovat do společnosti. Občané také vyjadřují aktivní zájem se s anglicky mluvícími cizinci setkat. Zmíněný fakt činí pro všechny imigranty život v ČR podstatně př́ijemnější a dodává jim snahu se rychleji a aktivněji aklimatizovat do naší země.

Největším problémem pro život v České republice jsou dle mínění respondentů nízké mzdy. Přestože pro anglicky mluvící imigranty není problémem se uplatnit na trhu práce, není to vždy zaměstnání a mzda, které by prímo odpovídalo jejich požadavkủm. Obtížnější proces při získávání zaměstnání a povolení zaměstnávat osoby (špatný kontakt a komunikace $\mathrm{s}$ úřady) byl zaznamenán u cizinců z nečlenského státu Evropské unie. V případě, že chtějí posílat peníze do svého státu nebo naopak je dalším negativem nízký směnný kurz. Cizinci z USA označili mimo jiné jako negativum př́liš vysokou cenu pohonných hmot. Dále všichni z dotazovaných poukázali na nevrlost, neochotu občanů České republiky, především na veřejných místech jako jsou úr̆ady nebo restaurace. V oblasti pedagogiky je označeno jako negativum zastaralé školství (výukou i vybavením).

Česká společnost nemá žádné větší výhrady vůči zkoumaným cizincům. Vidí jejich př́íchod spíše jako krátkodobou či střednědobou pracovní migraci. Většina je přesvědčena, že jejich uplatnění na trhu práce není nikterak komplikované. Názory české společnosti na důvody imigrace do České republiky se víceméně shodovaly s realitou.

\section{Závěr}

Co se týče anglicky mluvících imigrantů, jejich prríchod je zapříčiněn především z ekonomických důvodů. Využívají svůj rodný jazyk v denní komunikaci a jsou za to placeni. Pracovní migrace předpokládá prŕíchod cizinců $\mathrm{v}$ produktivním věku, což se děje. $Z$ výsledků imigrace konkrétně anglicky mluvících cizinců (obrázek č. 3) je vidno, že hospodářská krize ani žádné další aspekty neovlivnily jejich imigraci do České republiky, tudíž výsledkem je, že jejich uplatnění na trhu práce v období krize není žádným zásadním způsobem ovlivněno. Pro nikoho z dotazovaných nebyl problém získat práci v České republice. Se standardními kvalifikacemi a zkušenostmi a především rodnou angličtinou by to pro žádného anglicky mluvícího cizince ani problém být neměl. Tři imigranti $\mathrm{z}$ dotazovaných dokonce realizovali v hostitelské zemi své podnikatelské záměry, vybudovali vlastní jazykovou školu. Zaměstnávají zde jak obyvatele České republiky, tak jiné rodilé mluvčí, kteří vyučují svůj rodný jazyk. Dle neoklasické teorie migrace je proces migrace zapříčiněn dvěma faktory, a to push a pull faktory. Při aplikaci této teorie na výsledky výzkumu lze vymezit pull faktory, tj. motivy výběru imigrace do České republiky. Česká republika je atraktivní především díky poptávce po zahraniční pracovní síle na trhu práce, možností socioekonomického růstu a nízkým nákladům. Vedle ekonomických důvodů migrace je zde zájem o rozmanitější kulturní prostředí a historickou atmosféru, krásnou prŕrodu a jiné společenské hodnoty. Negativem jsou nízké mzdy, nižší rozmanitost pracovních příležitostí, komunikace s úřady a $\mathrm{v}$ restauracích, nízký směnný kurz, drahé pohonné hmoty a zastaralé školství. 


\section{Literatura}

[1] DRBOHLAV, D. Mezinárodní migrace obyvatel v Česku (s důrazem na vybrané demografické a ekonomické aspekty. Revue d'etudes comparatives Est-Ouest, 2009, 40, č. 1, s. 145-174. ISSN: 0338-0599

[2] DRBOHLAV, D., Uherek, Z. Reflexe migračních teorií. In Geografie. Sborník České geografické společnosti, 2007, 112, č. 2, s. 125 - 141. ISSN 1212-0014.

[3] CHALuPA, P., Hübelová, D. Globální recese a regionální rozvoj České republiky. In Geografické informácie 16. Nitra: UKF FPV, 2012. s. 106 - 116. ISSN 1337-9453. ISBN 97880-8094-637-1.

[4] HORÁKOVÁ, M. Vývoj pracovních migraci v České republice v obdobi hospodářrsé recese. Praha: Výzkumný ústav práce a sociálních věcí, 2010, 93 s. ISBN nezjištěno. Dostupné z: $<$ http://praha.vupsv.cz/Fulltext/vyrocka VUPSV-2010.pdf $>$.

[5] HÜBELOVÁ, D. Cizinci na území České republiky. In Sborník přispěvků z mezinárodní vědecké konference Region v rozvoji společnosti 2012 [CD-ROM]. Sborník př́spěvků ze 4. konference konané 18. 10. 2012. Brno: FRRMS, 2012, s. 93 - 98. ISBN 978-80-7375-652-9.

[6] MINAŘÍK, B. Statistika I Popisná statistika - druhá část. Brno: Mendelova zemědělská a lesnická univerzita, 2008, 226 s. ISBN 978-80-7375-152-4.

[7] VAVREJNOVÁ, M. Migrace obyvatelstva jako faktor ekonomického rozvoje. Praha: Národohospodářský ústav Josefa Hlávky, 2011. 79 s. ISBN: 978-80-86729-66-4. 